\title{
Head injury in heroes of the Civil War and its lasting influence
}

\author{
Victor M. Sabourin, MD, ${ }^{1}$ Ryan Holland, BA, ${ }^{1}$ Christine Mau, MD, ${ }^{1}$ Chirag D. Gandhi, MD, ${ }^{1-3}$ and \\ Charles J. Prestigiacomo, MD'1-3
}

Departments of ${ }^{1}$ Neurological Surgery, ${ }^{2}$ Radiology, and ${ }^{3}$ Neurology, Rutgers New Jersey Medical School, Newark, New Jersey

\begin{abstract}
The Civil War era was an age-defining period in the history of the United States of America, the effects of which are still seen in the nation today. In this era, the issue of head injury pervaded society. From the president of the United States, Abraham Lincoln, to the officers and soldiers of the Union and Confederate armies, and to the population at large, head injury and its ramifications gripped the nation. This article focuses on 3 individuals: Major General John Sedgwick, First Lieutenant Alonzo Cushing, and Harriet Tubman, as examples of the impact that head injury had during this era. These 3 individuals were chosen for this article because of their lasting legacies, contributions to society, and interesting connections to one another.
\end{abstract}

http://thejns.org/doi/abs/10.3171/2016.3.FOCUS1586

KEY WORDS neurosurgical history; American Civil War; head injury; John Sedgwick; Alonzo Cushing; Harriet Tubman

\begin{abstract}
As I looked at the President, he appeared to be dead. His eyes were closed and his head had fallen forward... I lifted his eyelids and saw evidence of a brain injury. I quickly passed the separated fingers of both hands through his blood matted hair to examine his head, and I discovered his mortal wound. The President had been shot in the back part of the head, behind the left ear. I easily removed the obstructing clot of blood from the wound, and this relieved the pressure on the brain. ${ }^{40}$
\end{abstract}

\section{- Dr. Charles Augustus Leale}

On April 14, 1865, President Abraham Lincoln was shot in the back of the head by John Wilkes Booth while attending a performance of "Our American Cousin" at Ford's Theater. ${ }^{17,40,52}$ Twenty-three-year-old Dr. Charles Augustus Leale, assistant surgeon of the US Volunteers, who had recently graduated from Bellevue Hospital Medical College, was the first physician to arrive on the scene.$^{52}$ Leale first thought that the president had been stabbed as he saw Booth wielding a dagger as he escaped. ${ }^{17,40}$ However, he soon discovered the president's head injury and believed the president would most likely not survive. Indeed, at 7:22 on the morning of April 15, 1865, President Abraham Lincoln died of the traumatic penetrating brain injury. ${ }^{17,42}$ His untimely death came days after the fall of the Confederate capital at Richmond, the surrender of General Lee and the Army of Northern Virginia, and a dream in his sleep in which Lincoln foresaw his own corpse in the East Room of the White House. ${ }^{17,39}$

Ironically, before the outbreak of the Civil War, a saying in the South was that "a lady's thimble will hold all the blood that will be shed" as a result of the secession of Southern states. ${ }^{39}$ Considered to be the first modern war in US history, the disastrous American Civil War resulted in an estimated 620,000 deaths between the Union and Confederate armies; statistically, 1 in every 4 soldiers died. ${ }^{4,18,19,60}$ But similar to wars in the past, it was still disease that killed the majority of soldiers in the Confederate and Union armies. ${ }^{18,19,23}$ The scale of the military engagements that occurred was unprecedented at that time; the armies of the Union and Confederacy at battle could number in the tens of thousands of men, and the battles could result in thousands of wounded in addition to those killed in action. ${ }^{4,18,19,37,39}$ Originally established in 1775 during the War for Independence, the military medical department had faced several wars leading up to the American Civil War. ${ }^{18-21}$ But in 1860 , a year before the American

ABBREVIATIONS MGH = Massachusetts General Hospital. 
Civil War erupted, there were only 30 surgeons and 83 assistant surgeons for the entire army; 24 of these men would later resign to join the Confederacy, and another 3 were dismissed for disloyalty. ${ }^{18,19,53}$ To deal with the new medical logistical challenge the war presented, the Union's medical department would completely overhaul its system. $18,19,23,37,39,53$

The treatment of head injuries during the American

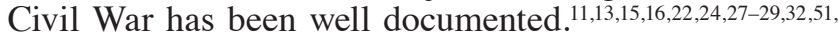
54-55,57,60 In particular, the multivolume Medical and Surgical History of the War of the Rebellion remains one of the most useful sources of information regarding the neurosurgical treatment of injured Union soldiers. ${ }^{4,18,32,37,57,59}$ While they were alive, the 3 individuals selected for discussion in this article bore significant influence on the military and cultural spheres of their times. However, the impact of head injury during the American Civil War era is unique because of its all-inclusive influence on the medical, military, cultural, and political structure of a world whose remnants still linger on in the US today.

\section{Major General John Sedgwick}

John Sedgwick (Fig. 1) was born on September 13, 1813, in Cornwall Hollow, Connecticut, and was raised on his family's farm. ${ }^{47,56,58}$ However, Sedgwick was ambitious and did not want to live a life of farming. ${ }^{56,58} \mathrm{He}$ entered the United States Military Academy (West Point) on July 1,1833 , and graduated 24th in his class of 50 students in July of 1837 as a second lieutenant in the artillery. ${ }^{47,58}$ From that point forward, John Sedgwick would serve as

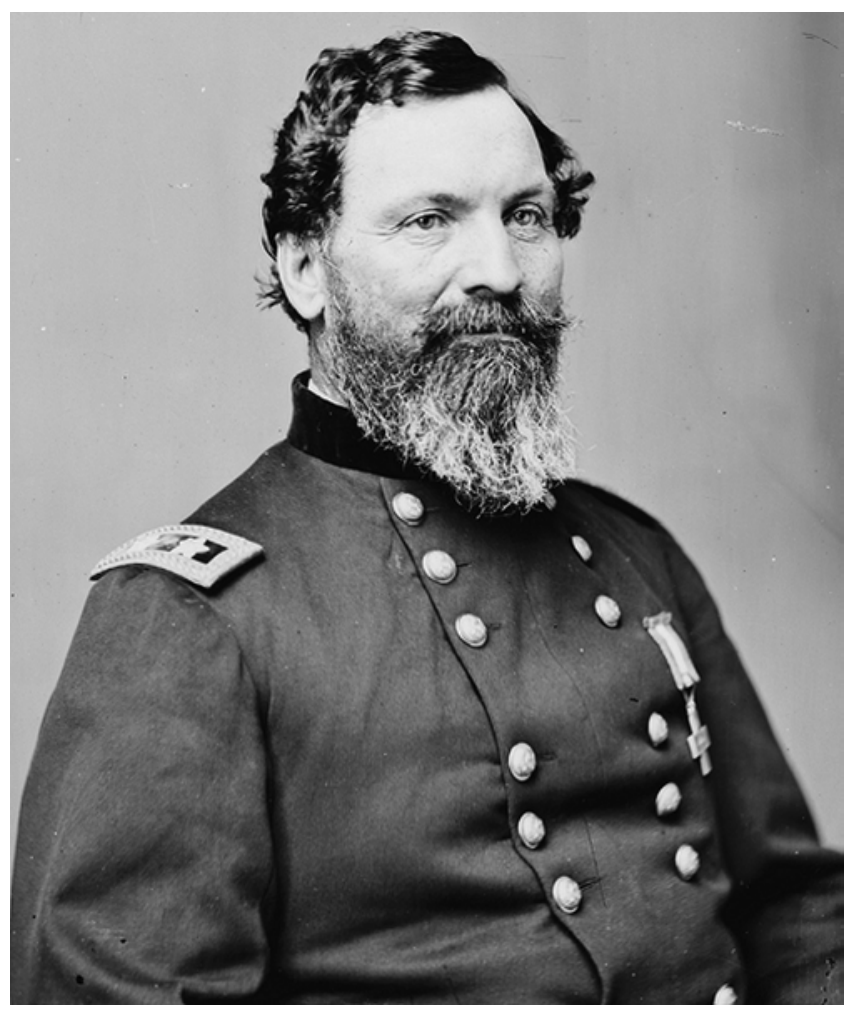

FIG. 1. Major General John Sedgwick (1813-1864). Library of Congress. (Public domain: http://www.loc.gov/pictures/item/cwp2003000380/PP/) an officer and would make significant military contributions over the course of his career. ${ }^{47,56,58}$ Sedgwick's military career after his graduation was tumultuous. His tour of duty took him across the country to Florida during the war against the Seminoles, then north during the Canadian rebellion, and south once again to Texas and Mexico for the Mexican War. ${ }^{49,56,58}$ After the Mexican War, Sedgwick was sent to Kansas during the "Bleeding Kansas" events, where the issue of slavery became a dividing point, and perhaps portended the dispute over slavery leading up to and into the American Civil War. ${ }^{39,49,56}$ In 1860, after 23 years of service, the 47-year-old John Sedgwick was seriously considering retirement in the spring of $1861 .^{56,58}$ The election of President Lincoln had brought considerable turmoil to the country and Sedgwick was unsure how a breakup of the Union would affect him, stating that it "probably would result in my leaving the service at once." ${ }^{47,58}$ But when Confederate forces attacked Fort Sumter in April of 1861, Sedgwick, being a man of honor, "felt that, educated at his country's expense, he could not desert her in her hour of need."'56,58

Sedgwick was known for being a simple and humble man who was well loved by his soldiers, who called him "Uncle John," and respected among his superiors and enemies, including General Robert Lee of the Confederate forces. ${ }^{36,49,56,58}$ Major General George McClellan, who led the Army of the Potomac, and who was a Democratic nominee for the 1864 presidential election and governor of New Jersey, even once said:

He [Sedgwick] was one of the best and most modest soldiers we had. Possessing excellent ability and judgment, the highest bravery, great skill in handling troops, wonderful powers in instructing and disciplining men, as well as gaining their love, respect, and confidence.... He was thoroughly unselfish, honest, and true as steel. ${ }^{36}$

It was Sedgwick's upstanding character traits as a gentleman and soldier that made him a popular leader among the tens of thousands of men he commanded.$^{58} \mathrm{He}$ would routinely put himself in dangerous situations within range of enemy fire, would not pay heed to the "showers of bullets," and would do what was necessary. Part of Sedgwick's combat philosophy was clear: to be calm, cool, and collected in the face of enemy fire even when in mortal danger, and to lead by example. However, Sedgwick would not escape all of his battles unscathed. At the Battle of Antietam, Sedgwick was sequentially shot in his leg, wrist, and shoulder. Although at first he refused to leave the combat zone and relinquish command, he was carried off the battlefield 1 hour after sustaining his first injury.

\section{The Impact of General Sedgwick}

Throughout the Civil War, Sedgwick made significant contributions to the Union's military campaign. On February 6,1862 , he was promoted to brigadier general of the volunteers and given 13,000 men to lead and command. ${ }^{58}$ During the Battle of Fair Oaks, Sedgwick proved his worth by arriving at the height of the battle to stop Confederate General Johnston's advance and flanking of Union forces. Sedgwick accomplished this task by trailblazing a path across the Chickahominy River that the Confederate gen- 
erals deemed an impossible military maneuver. Sedgwick and his men had successfully altered the flow of the battle in favor of the Union forces and in doing so helped conserve the Union's fighting strength. Sedgwick had clearly proved himself a reliable officer who could be trusted to successfully lead large numbers of soldiers against the Confederacy. It is therefore unsurprising that by July of 1862, Sedgwick had risen to the rank of major general.

After the Second Battle of Bull Run, which ended in a Union defeat, the Union forces were in full retreat from the pursuing Confederate forces. During this time period, Sedgwick acted alone as Lincoln and the Union military high command rushed to put together a defense line for the capital. ${ }^{58}$ To provide aid to the retreating Union forces, Sedgwick and his men made "a forward march, one which for its length and rapidity has not been equaled in this war; in thirty-six hours... [they marched] fifty miles, and after a rest of a few hours twenty-five miles more." ${ }^{\prime 7,58}$ However, due to their efforts, Sedgwick and his men were able to slow General Lee's assault and provide invaluable time for the Union forces. ${ }^{58}$

Sedgwick's responsibilities continued to grow within the Army of the Potomac. By 1863 he had become commander of the 6th Corps and was leading approximately 24,000 men. ${ }^{58}$ At the Battle of Gettysburg, Sedgwick's men were spread out along the entire line of Union forces to bolster numbers and were not directly under his command. However, it should be noted that among the soldiers of Sedgwick's 6th Corps, Captain Cowan in particular served with distinction at Gettysburg. Captain Cowan and his battery positioned at The Angle were at the center of Pickett's Charge, and helped to hold the line along with Lieutenant Alonzo Cushing against overwhelming numbers of Confederate troops. After the battle, as Lee's forces were in retreat, Sedgwick and his men were picked by the commander of the Army of the Potomac, General Meade, to pursue General Lee and his Confederate forces.

At the Battle of the Wilderness, Sedgwick turned an imminent defeat into a tactical placement of his troops. Fighting had suddenly broken out as Sedgwick conferred with his staff, and the 6th Corps line of defense seemed to be breaking down. However, Sedgwick himself rode out to bolster their defenses and "everywhere he went he held the line by his personality." 58 Sedgwick and his men then worked by lantern light to plan new positions of soldiers to successfully reestablish their line of defense. General Grant in his report of the battle stated that although Sedgwick had almost been overtaken by a Confederate attack, this was due to a multitude of factors, many of which were out of Sedgwick's control. Although taken by surprise, the 6th Corps were able to respond appropriately and avert a potentially disastrous series of events. General Sedgwick had proved himself to be an experienced military general: able to lead a corps of men, successfully launch an attack, and expertly defend his line in highly stressful and chaotic situations. However, after the Battle of the Wilderness, Sedgwick led his men to the Battle of Spotsylvania where he would meet his end (Fig. 2).

\section{The Death of General Sedgwick}

Ultimately, it was Sedgwick's brazen nature in the face of enemy fire that would cost him his life. ${ }^{46,58}$ At the Battle of Spotsylvania Court House, Sedgwick noticed that some of his troops were not in the proper position and had moved to fix their placement, when bullets from Confederate sharpshooters began whistling by. Sedgwick's men began dodging and ducking for cover, while Sedgwick laughingly stated:

What! What! Men dodging this way for single bullets! What

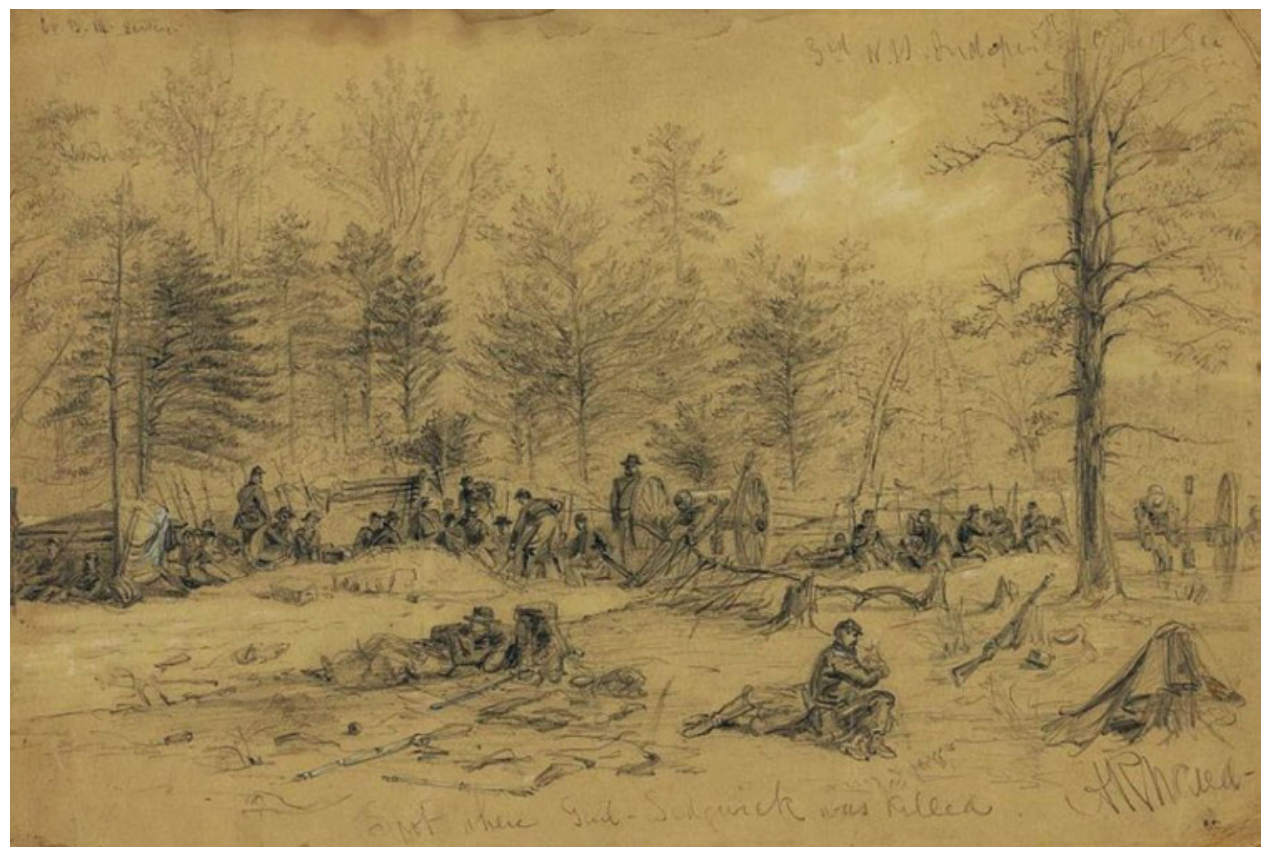

FIG. 2. Artist's rendering of the spot where General Sedgwick was killed. Artist: Alfred R. Waud, 1864. Library of Congress. (Public domain: http://www.loc.gov/pictures/item/2004660899/) 
will you do when they open fire along the whole line? I am ashamed of you. They couldn't hit an elephant at this distance. ${ }^{31}$

A sergeant next to Sedgwick then explained how he had once dodged a shell and if he had not, it would have taken his head off, and therefore he believed in its merits. ${ }^{31,46}$ Sedgwick laughed and told the man to return to his position. ${ }^{46}$ Another bullet came whistling through, however; this time a dull thump was heard and General Sedgwick fell to the ground with a bullet wound below his left eye. ${ }^{46,58}$ On May 9, 1864, almost 31 years after first entering West Point, Major General John Sedgwick of the Army of the Potomac had been killed at the start of the Battle of Spotsylvania Court House (Fig. 3). Unfortunately, it seems that an autopsy was never performed, making it difficult to piece together the fatal head injury. ${ }^{45}$ In addition, the sniper's identity has never been confirmed.

Sedgwick's death that day was such a shock that General Grant twice questioned whether Sedgwick had really died, stating that Sedgwick's death was greater than the loss of a division of soldiers. ${ }^{58}$ It has been said that although Sedgwick was not a military genius, his "endur-

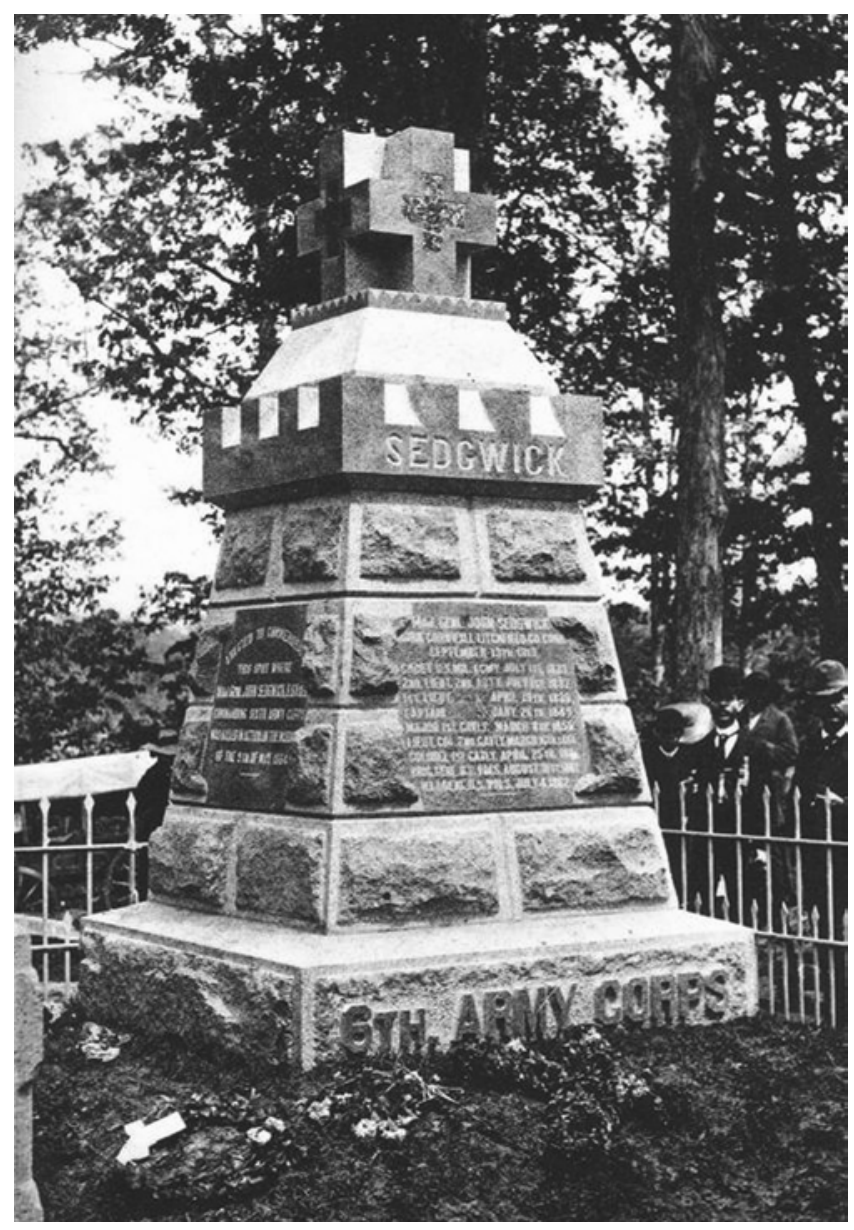

FIG. 3. Monument to Major General John Sedgwick, at the location where he was killed during the Battle of Spotsylvania on the morning of May 9, 1864. The monument was dedicated on May 12, 1887; photograph was taken in 1887. Sedgwick Memorial Association; 6th Army Corps. (Public domain: https://archive.org/details/sedgwickmemorial 01sedg) ance and steadfastness" were important traits for the grueling American Civil War. It is undeniable that by the time of his death, Sedgwick had more than proven his usefulness as a general of the Union. Had he survived, he would have undoubtedly continued to play a pivotal role in the American Civil War, hasten its end, and help bring peace to the war-torn nation.

\section{First Lieutenant Alonzo Cushing}

Born in Wisconsin on January 19, 1841, to the impoverished couple Milton and Mary Cushing, Alonzo Cushing's childhood was fraught with difficulty. ${ }^{10,25,49}$ By the time he was 6 years old he had already lost his father and a number of his siblings to tuberculosis. ${ }^{10,25}$ After his father's death, Alonzo and his family moved to Fredonia, New York, where Milton grew up and where his extended family lived. Although life in Fredonia was not easy, Mary Cushing was able to find a job and provide for her family.

On July 1, 1857, after a rigorous preadmittance training period, Alonzo was formally admitted to the United States Military Academy at 16 years of age. ${ }^{10,25,49}$ When Alonzo enrolled at West Point, the original time line for his graduation spanned 5 years. ${ }^{10}$ The 5-year policy was instituted by the former Secretary of War, Jefferson Davis, who went on to become a senator for the state of Mississippi and then president of the Confederate States. ${ }^{10,39}$ However, due to the outbreak of the American Civil War, the 5th year was shortened to a 2-month period for Cushing and his classmates. ${ }^{10}$

Alonzo's academic career at West Point spanned the outbreak of the Civil War, which caused a severe rift between the Northern and Southern supporters within West Point. ${ }^{10}$ Of the original 68 students who had qualified for admission in Alonzo's year, only 35 remained at the time of graduation. The majority of the students who left from the class resigned because of their support for the Confederacy.

The Cushing family believed that slavery was immoral. ${ }^{10}$ In fact Alonzo's father, Milton, was a strong believer in the abolitionist movement and previously supported it by providing his home as a station in the abolitionist Underground Railroad system. Therefore, Alonzo's opinion on the matter of the Southern separatists was clear; he supported Abraham Lincoln's standpoint on slavery and wanted to fight in the war against the Southern rebels. On June 24, 1861, Alonzo Cushing (Fig. 4) was commissioned as a second lieutenant and soon thereafter as a first lieutenant in the 4th United States Artillery, and reported for duty in Washington, D.C. ${ }^{10,25}$ Though Alonzo's military career would prove to be quite successful, it would end prematurely on the battlefield at Gettysburg.

\section{The Death of Alonzo Cushing}

The Battle of Gettysburg (Fig. 5) was a 3-day battle that was fought from July 1 to July 3, 1863, and by this time Alonzo had already proven his skills as a military leader. ${ }^{10,25,37,39} \mathrm{He}$ had been brevetted to the rank of captain and then major for his services at the Battles of Fredericksburg and Chancellorsville, Virginia, respectively. ${ }^{10,25}$ However, Alonzo was unable to escape from the torrent of blood that 


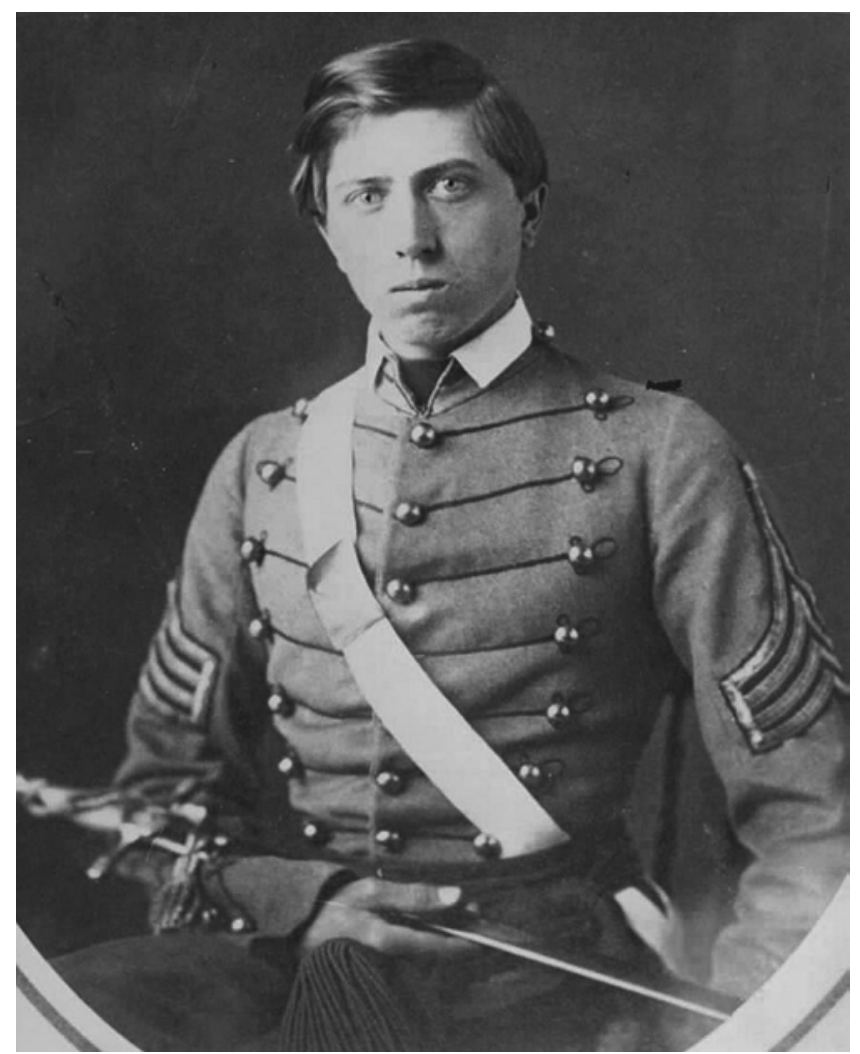

FIG. 4. Cadet Alonzo Cushing (1841-1863) in his West Point class photograph, taken in 1861 (US Army). (Public domain: http://www.army.mil/ media/360417)

the Battle of Gettysburg would leave in its wake. The battle would ultimately produce more than 50,000 casualties between the Union and Confederate armies, with Alonzo Cushing numbering among the fallen..$^{10,25,37,39}$

On July 3, 1863, General Robert E. Lee put into action a massive artillery assault followed by a coordinated charge on the Union's center along Cemetery Ridge. ${ }^{10,39,44}$ Approximately 150 artillery guns amassed along Seminary Ridge and began firing upon the Union's center forces to weaken the defenses. Such was the exchange of artillery fire between the Confederate and Union armies that the bombardment could be heard more than 100 miles away in Pittsburgh, Pennsylvania. ${ }^{39}$ Cushing and his battery of 6 guns, positioned at The Angle of Cemetery Ridge, was actively engaged as his soldiers and horses were being decimated by the deadly Confederate artillery fire. ${ }^{10,25}$ During this exchange, Cushing was wounded in his right shoulder and then his groin by shell fragments. Despite his wounds Cushing refused to leave the battlefield, stating that he would continue to fight or die in the process. ${ }^{10}$ Weak from his bleeding wounds, Cushing was unable to give his commands above the noise of artillery fire, and so asked First Sergeant Frederick Fuger to relay his orders for him. As the Confederate fire abated, the destruction it had caused was evident..$^{39}$ Of the 6 guns that Cushing had in his unit at the initiation of the battle, only 2 were still serviceable. ${ }^{10}$ After conferring with a superior officer, Cushing suggested that he advance his remaining guns to the stone wall to help repel the ensuing charge of Confederate soldiers. ${ }^{10,39}$ Despite wounds that would qualify him to be relieved of duty, Cushing decided to advance his guns closer to the enemy to help hold the Union line of defense..$^{10,25}$

In what has become known as Pickett's Charge, Generals Pickett, Pettigrew, and Trimble, along with 3 divisions of Confederate soldiers that extended a mile in formation, charged across the battlefield to attack the Union's center. ${ }^{10,39,44}$ First Lieutenant Alonzo Cushing and his men of Battery A, 4th United States Artillery, Army of the Potomac, positioned at the focus of Pickett's Charge (Fig. 6), stood fast with 2 artillery guns in the face of thousands of Confederate infantrymen. ${ }^{10,25}$ Consequent to the frequent firing of his guns, the leather thumbstall, which is used

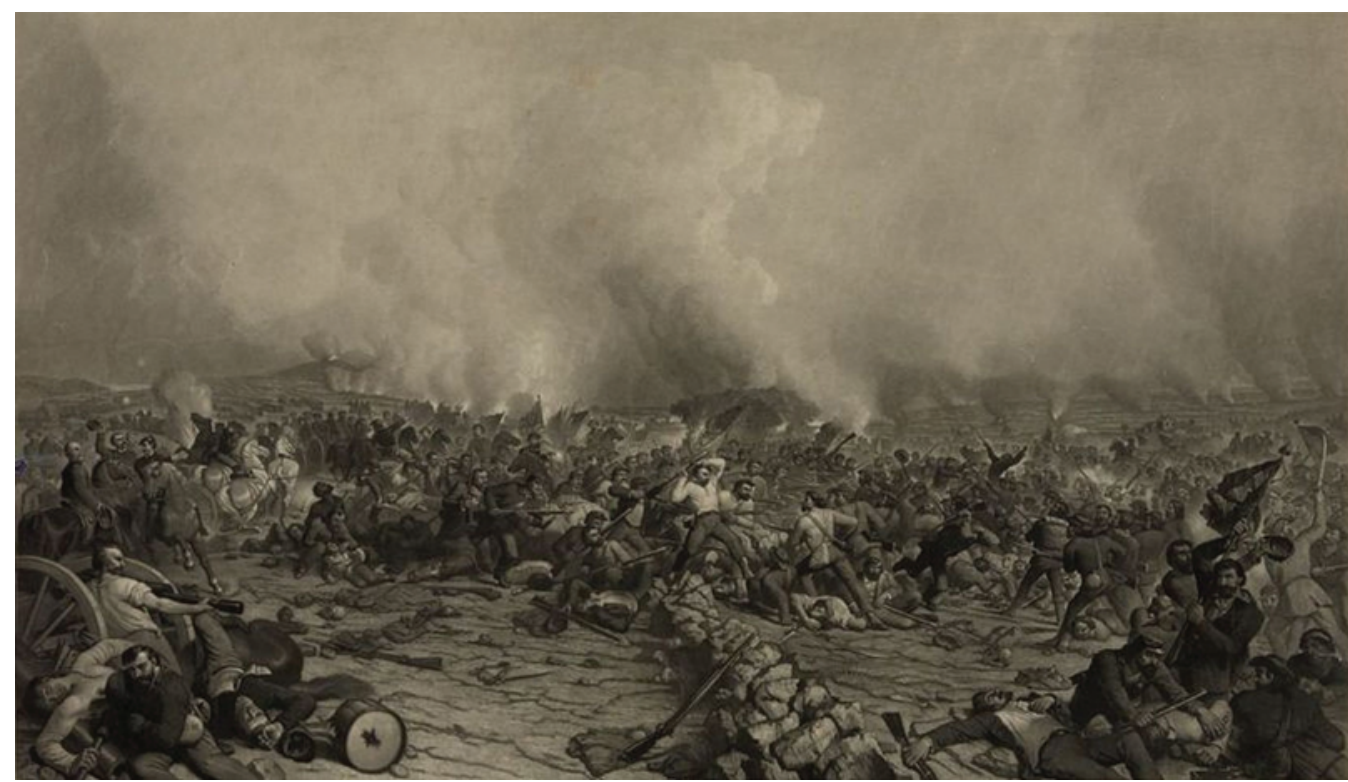

FIG. 5. Engraving of the Battle of Gettysburg, made in 1870. Artist: Peter Rothermel; engraver: John Sartain. Library of Congress. (Public domain: http://www.loc.gov/pictures/item/2006678602/) 

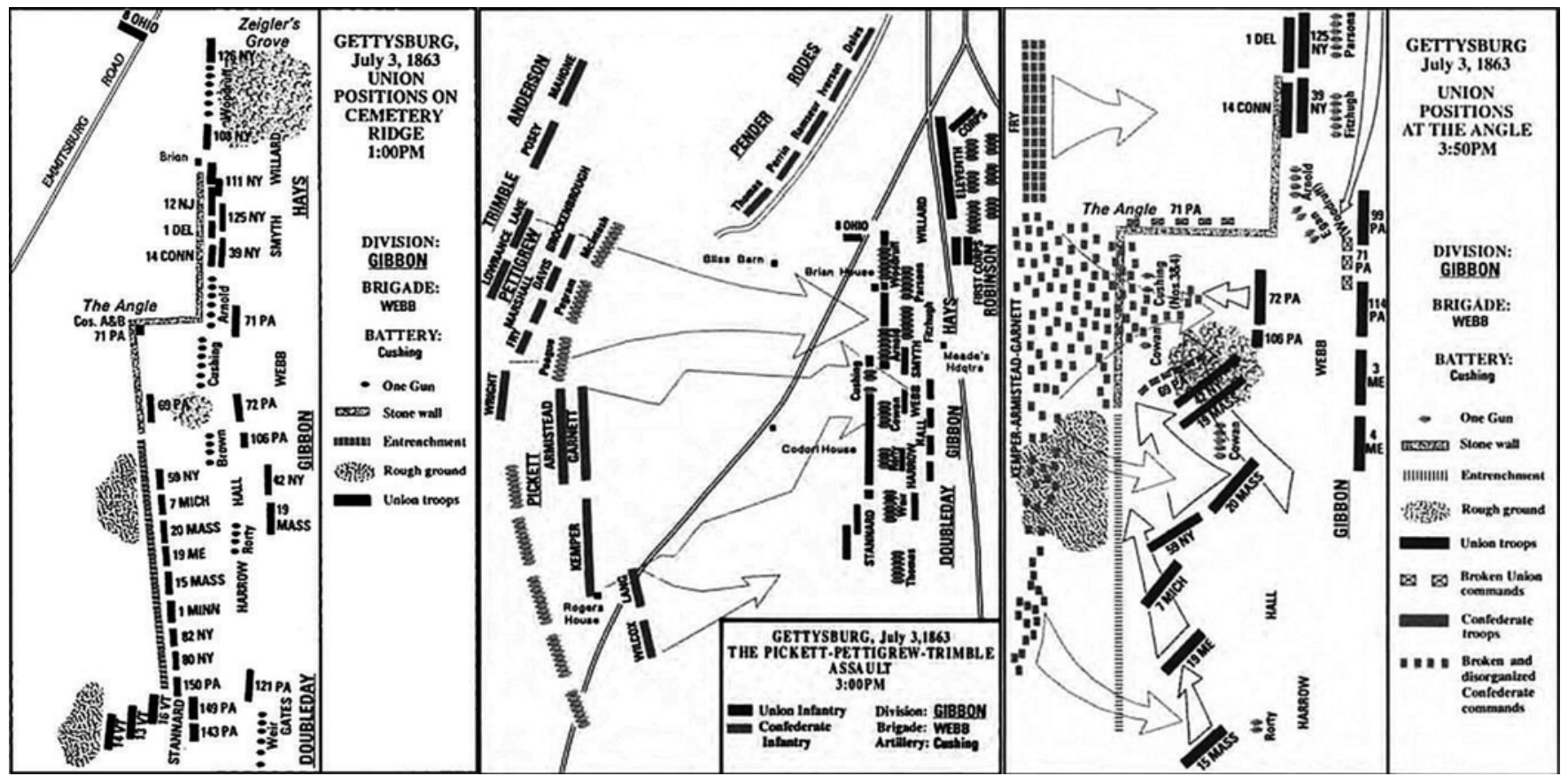

FIG. 6. Tactical maps of the Battle of Gettysburg on July 3, 1863. Left: Position of the Union forces along Cemetery Ridge, including the location of Cushing's battery of 6 guns at The Angle. Center: The Pickett-Pettigrew-Trimble charge. Note that Cushing was directly in line with Pickett's assault. Right: Confederate forces overrun Cushing's position at The Angle. By this point, Cushing had already been killed in action. Reprinted with permission from Brown KM: Cushing of Gettysburg: The Story of a Union Artillery Commander, University Press of Kentucky, 1993.

to shield the thumb against the hot gases of cannon firing, had been rendered useless, and so to fire his artillery gun, Cushing used his bare thumb as a stopper. ${ }^{10}$ The hot gases burned away at Cushing's thumb, exposing bone and causing excruciating pain. But Cushing persevered and ordered his 2 guns to be reloaded with a double shot of canister. Having exhausted all the ammunition for one of his cannons, the cannoneers improvised by using shrapnel from exploded shells, rocks, bullets, and a bayonet. The men were ready and awaited their leader's command. Immediately after giving the order to fire (which was relayed through Sergeant Fuger), a bullet passed through Cushing's mouth, lodging into the base of his skull. ${ }^{10,25}$ Cushing died on July 3, 1863, at the height of Pickett's Charge..$^{10,25,26}$

\section{The Impact of Alonzo Cushing}

There is no shadow of a doubt that Cushing and his battery admirably served at Gettysburg above and beyond the call of duty. His actions at the height of Pickett's Charge helped clear the way for a Union victory at the Battle of Gettysburg, the aftermath of which caused General Lee's forces to rapidly retreat south. Alonzo Cushing was posthumously brevetted to the rank of lieutenant colonel for his services at Gettysburg. ${ }^{10,25}$ In addition, on July 6, 1863, the New York Times published an article on its front page featuring Alonzo Cushing and his heroic efforts at the Battle of Gettysburg..$^{10}$ More than 150 years later, on August 28, 2014, the New York Times published a front-page article in the New York edition announcing the posthumous bestowing of the Medal of Honor on Cushing for his actions on that fateful day in $1863 .{ }^{3}$ On November 6, 2014, President
Barack Obama officially awarded First Lieutenant Alonzo Cushing the Medal of Honor 151 years after his death, with Cushing's first cousin twice removed, Helen Loring Ensign, receiving the award on his behalf (Fig. 7). ${ }^{50}$

Bearing in mind his past, Cushing would have undoubtedly been joyous that the Union went on to defeat the Confederacy and abolish slavery from the United States of America. Had Alonzo Cushing survived he would have continued to serve meritoriously, perhaps even eventually

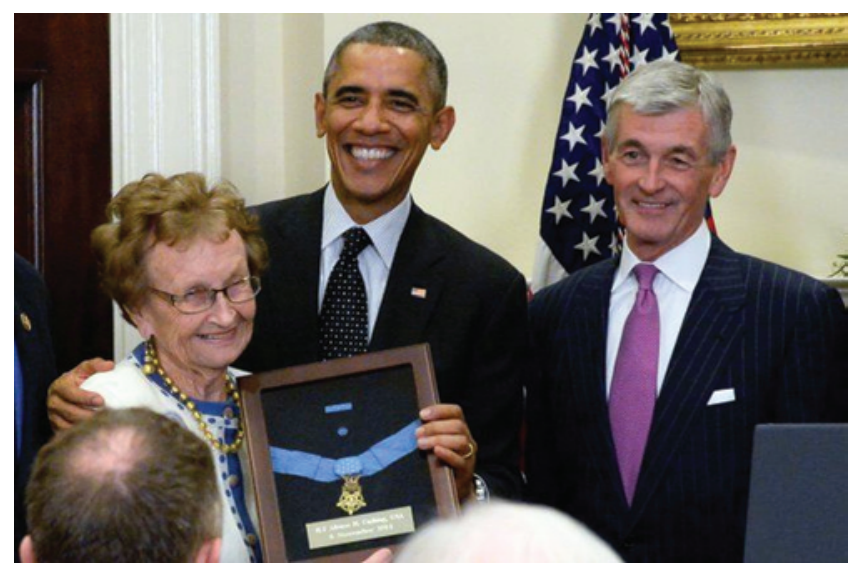

FIG. 7. Photograph of Alonzo Cushing's first cousin twice removed, Helen Loring Ensign, receiving the Medal of Honor from President Barack Obama on November 6, 2014. To the left of the president is Secretary of the Army John M. McHugh. Roosevelt Room of the White House, Washington, DC. Photograph credited to Staff Sergeant Laura Buchta (US Army). (Public domain: http://www.army.mil/media/371093) 


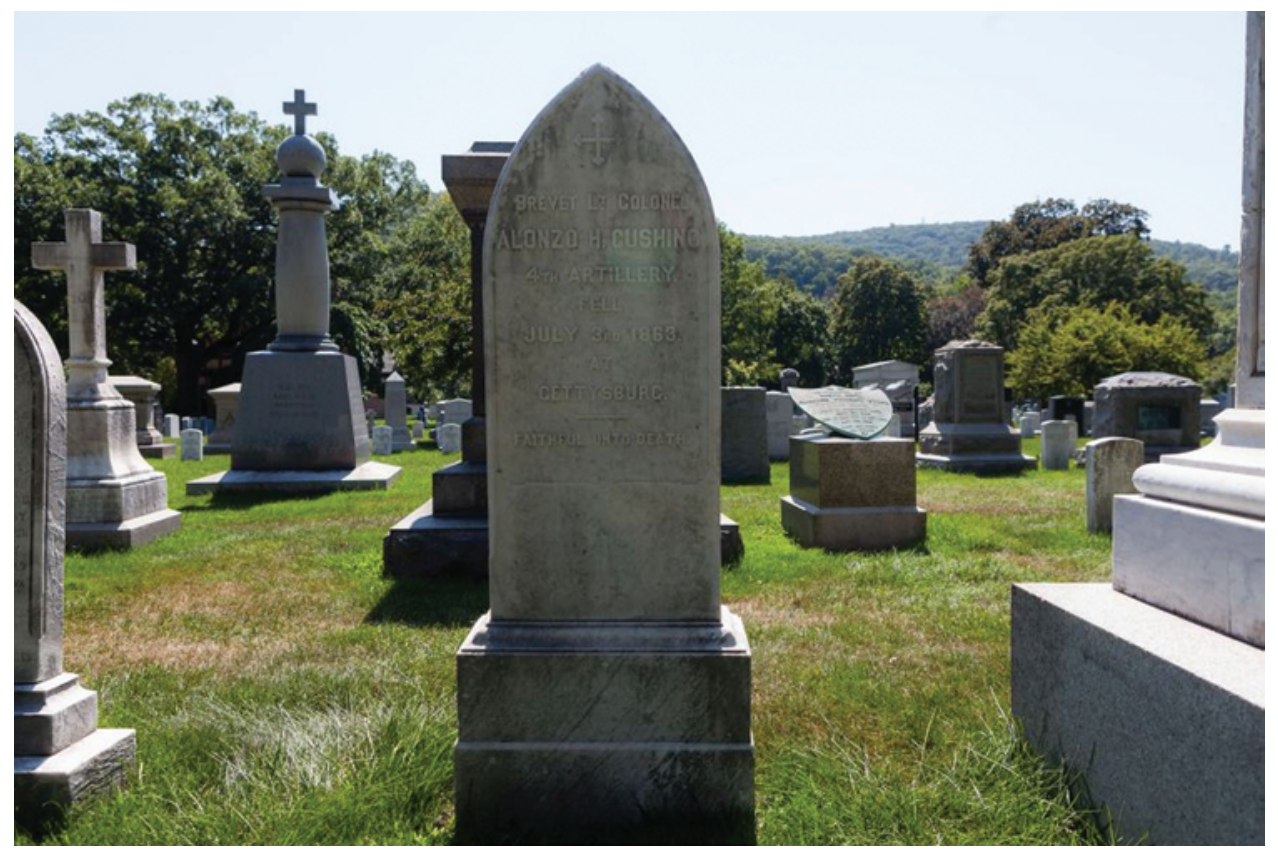

FIG. 8. Alonzo Cushing's headstone at West Point Cemetery, New York. Photograph courtesy of West Point Public Affairs. (Public domain: http://www.army.mil/medalofhonor/cushing/\#)

rising to the rank of general, considering his military feats and the path in which his career was developing. However, regardless of what rank he would attain, Cushing would have continued to contribute to the Union's cause of reuniting the United States of America and helping to create a free country for all who were part of it. Alonzo Cushing is buried at West Point Cemetery, New York, where the headstone that his mother had erected for him reads "Faithful Unto Death" (Fig. 8). ${ }^{10}$

\section{Harriet Tubman}

Harriet Tubman (Fig. 9), one of the most well-known figures involved in the American abolitionist movement, was born Araminta "Minty" Ross around the year 1822 in Dorchester County, Maryland..$^{14,35,43}$ Because she was born into slavery, records were not kept on her exact birth date. ${ }^{43}$ When she was younger, she was forced to act as a nursemaid for her brutal master, Miss Susan. ${ }^{12}$ Once her tenure was complete, she was sent to work on the plantation. At 13 years of age, Harriet was strong enough to work in the fields, where she harvested and processed acres of flax. ${ }^{35}$

That year, a slave on Harriet's plantation tried to escape out of the cornfields and ran into a local dry-goods store where Harriet happened to be. ${ }^{6,14}$ The plantation supervisor soon caught up with the slave and told Harriet to stop the boy from running further. ${ }^{6}$ When Harriet refused, the supervisor threw an iron weight that hit Harriet on the forehead.6,14,30,33 Tubman later described that the weight "broke [her] skull" and would have killed her had it not been for her thick hair which "stood out like a bushel basket."14,38 Bleeding and unconscious, Tubman was returned to her house without medical care. ${ }^{38}$ She had a scar and a clear deformity on her forehead, consistent with a depressed skull fracture. After this event, she was reported

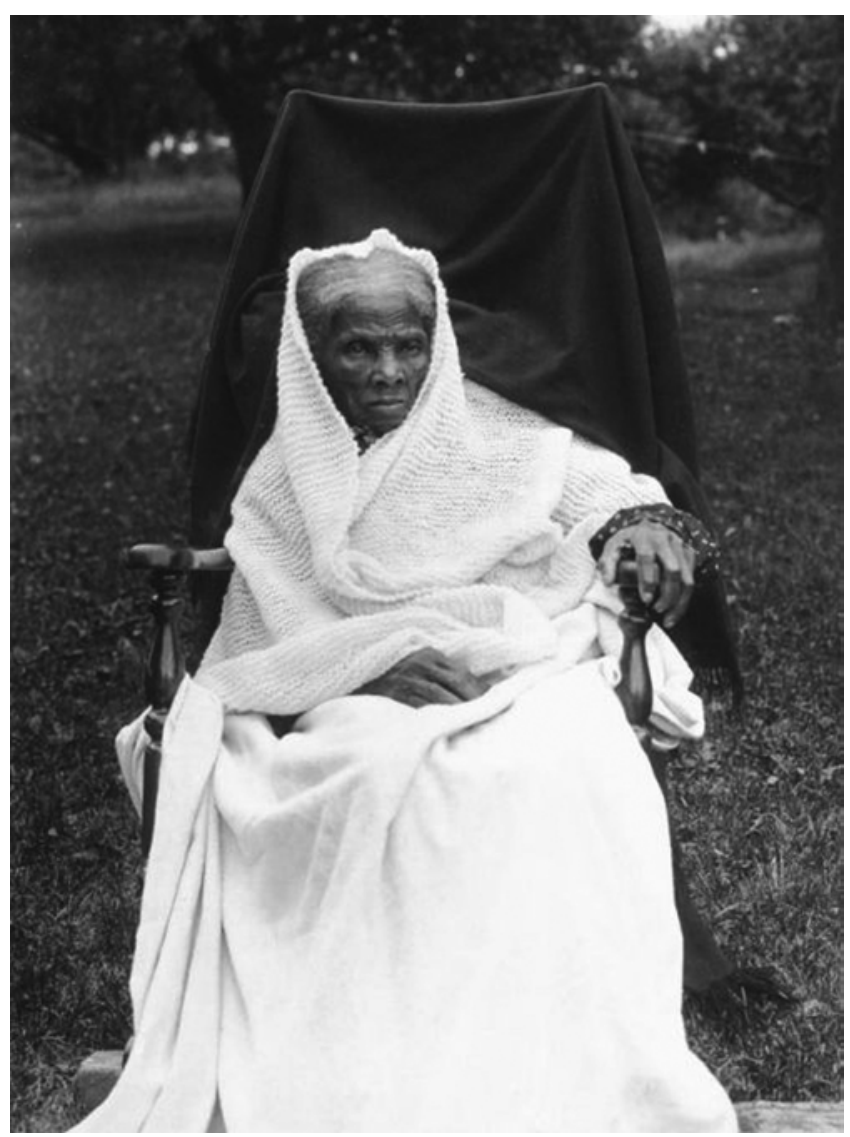

FIG. 9. Harriet Tubman (circa 1822-1913) sitting. Photograph taken in 1911. Library of Congress. (Public domain: http://www.loc.gov/pictures/ item/2002716779/) 
to suffer from "sleeping fits" which may have represented seizures. ${ }^{6,30}$ During these seizures, no one would be able to wake her until the episode was over. ${ }^{6}$ As described in some supporting literature, the seizures would put her into a trancelike state, but she remained aware of her surroundings during these episodes, suggesting that she may have suffered from absence seizures. ${ }^{38}$ Harriet believed she was able to speak with God during these episodes. ${ }^{30,35}$ She developed a deep religious faith that, like her seizures, stayed with her for the rest of her life. ${ }^{6,14,30}$

Religion was influential in many slaves' lives. In their quarters, they related their struggles to the Hebrew slaves that escaped from Egypt in the Old Testament. ${ }^{38}$ This gave them hope that someday they might be free. Like the Hebrew slaves, in the fall of 1849 , Harriet escaped in search of freedom..$^{30,41}$ She followed the Underground Railroad, a system of common paths and safe houses which escaped slaves could use, to make her way to Philadelphia where she could be free. Unfortunately, the Fugitive Slave Act of 1850 was passed soon afterward; this law required those in free states to help slave owners recapture and return runaway slaves. ${ }^{33,41}$ Instead of hiding because of her new status as a felon, she took additional trips to Maryland to help her family members escape to freedom. Tubman eventually made 13 of these harrowing trips.

\section{The Impact of Harriet Tubman}

During the Civil War years, Tubman supported the Union's efforts without compensation in the roles of "nurse, scout, and spy" (Fig. 10), ${ }^{2,14,30,41}$ One example of her contributions during the war came in South Carolina, along the Combahee River. There, with Colonel Montgomery, Tubman became the first woman to help plan and lead a military assault during the Civil War. ${ }^{33,41}$ Alongside the river were several rice plantations that housed hundreds of slaves as well as Confederate warehouses with supplies. ${ }^{33,35} \mathrm{~A}$ raid was needed to oust the Confederate forces who patrolled the river, to access the Confederate supplies, and also to free the slaves working on the plantations. The raid (Fig. 11) was a success and resulted in the freeing of more than 700 slaves, earning her the popular title of "General Tubman." "30,33,41,48

Although Tubman supported the Union's goal to eliminate slavery, she was not completely satisfied with President Lincoln's actions. ${ }^{30,33}$ On January 1, 1863, Lincoln's Emancipation Proclamation freed the slaves in the Confederate states. ${ }^{6,33}$ However, Tubman was critical of the president for not freeing the slaves who had escaped to the Northern states, and therefore considered the proclamation to be insufficient. She also disapproved of the disparity in pay between black and white soldiers during the Civil War. ${ }^{30,33,48}$ In fact, despite the opportunity to meet President Lincoln, Harriet's dislike of him during the Civil War era caused her to avoid him and only ever meet his wife. ${ }^{30,33}$ Later in her life, Harriet regretted that she never met Abraham Lincoln to thank him for all he had done.

Although this is speculative, it is interesting to note that Tubman's head injury and subsequent seizures, which she believed allowed her to speak to God, may have been a galvanizing force for her faith and passion to embark on her dangerous missions in support of the abolitionist

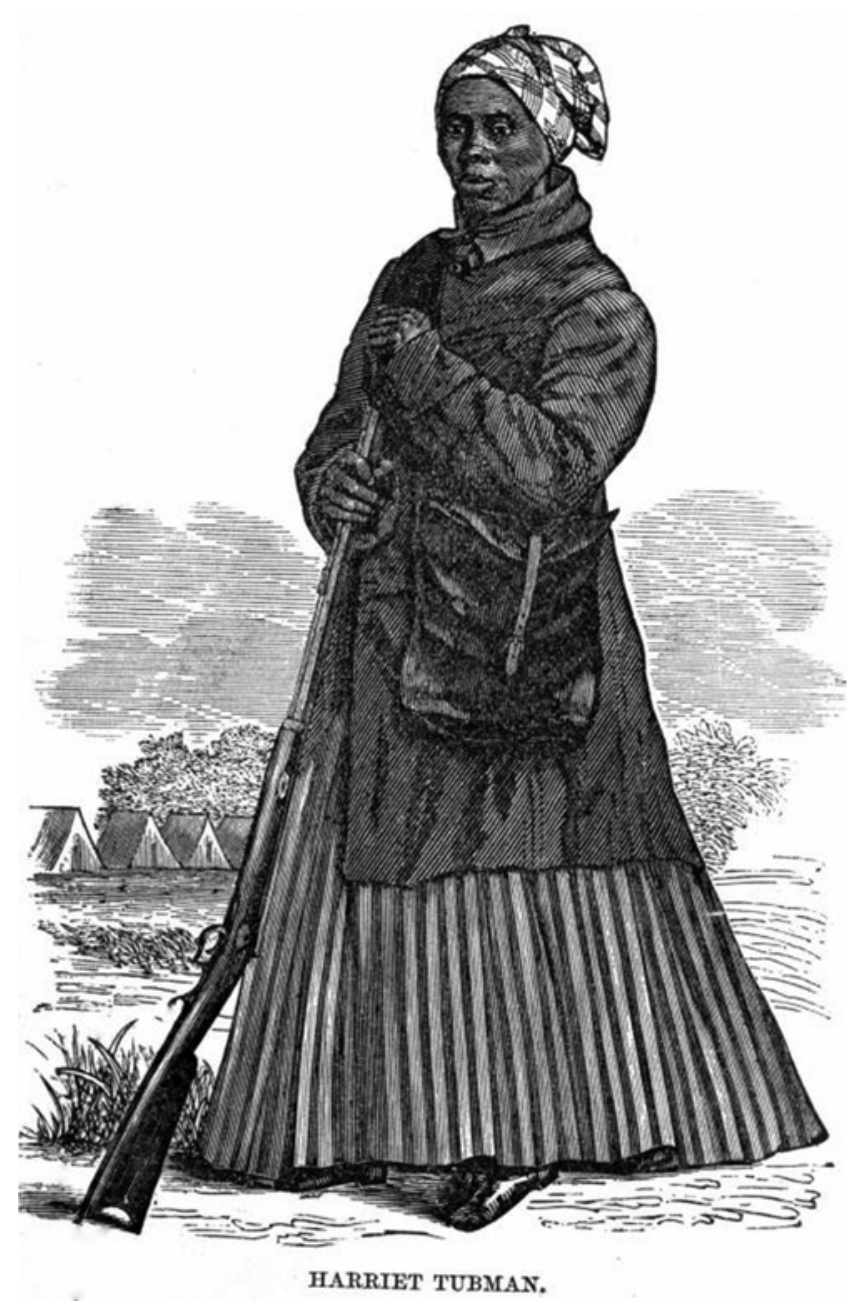

FIG. 10. Woodcut of Harriet Tubman depicted in her Civil War scout uniform, from Scenes in the Life of Harriet Tubman by Sarah Bradford, 1869. (Public domain: https://archive.org/details/scenesinlifeofha 1869brad)

movement and to organize and lead a raid against the Confederate Army. Tubman's contributions during the Civil War helped to lead the country toward a free nation.

After the war, Harriet Tubman continued to live with her seizures and persistent headaches, although their severity became unbearable., 1,733 Thus, in the 1890 s, Ms. Tubman underwent a craniotomy at the Massachusetts General Hospital (MGH) for what descriptions report to be an elevation of a depressed skull fracture, with a reported improvement in her headache syndrome. Of note, no anesthesia was used during the procedure because Harriet refused it and instead bit down on a bullet to deal with the pain as she had seen soldiers do for pain during amputations. ${ }^{1,33}$ However, the records of the surgery at MGH have never been found or released to the public because of guidelines regarding patient confidentiality. According to Jeff Mifflin, archivist at MGH, the physician who performed the most neurosurgical procedures at MGH during the late 1890s and into the early 20th century was Maurice $\mathrm{H}$. Richardson, MD. Therefore, although this conclusion is speculative, it is possible that it was Dr. Richardson who performed Tubman's surgery. 


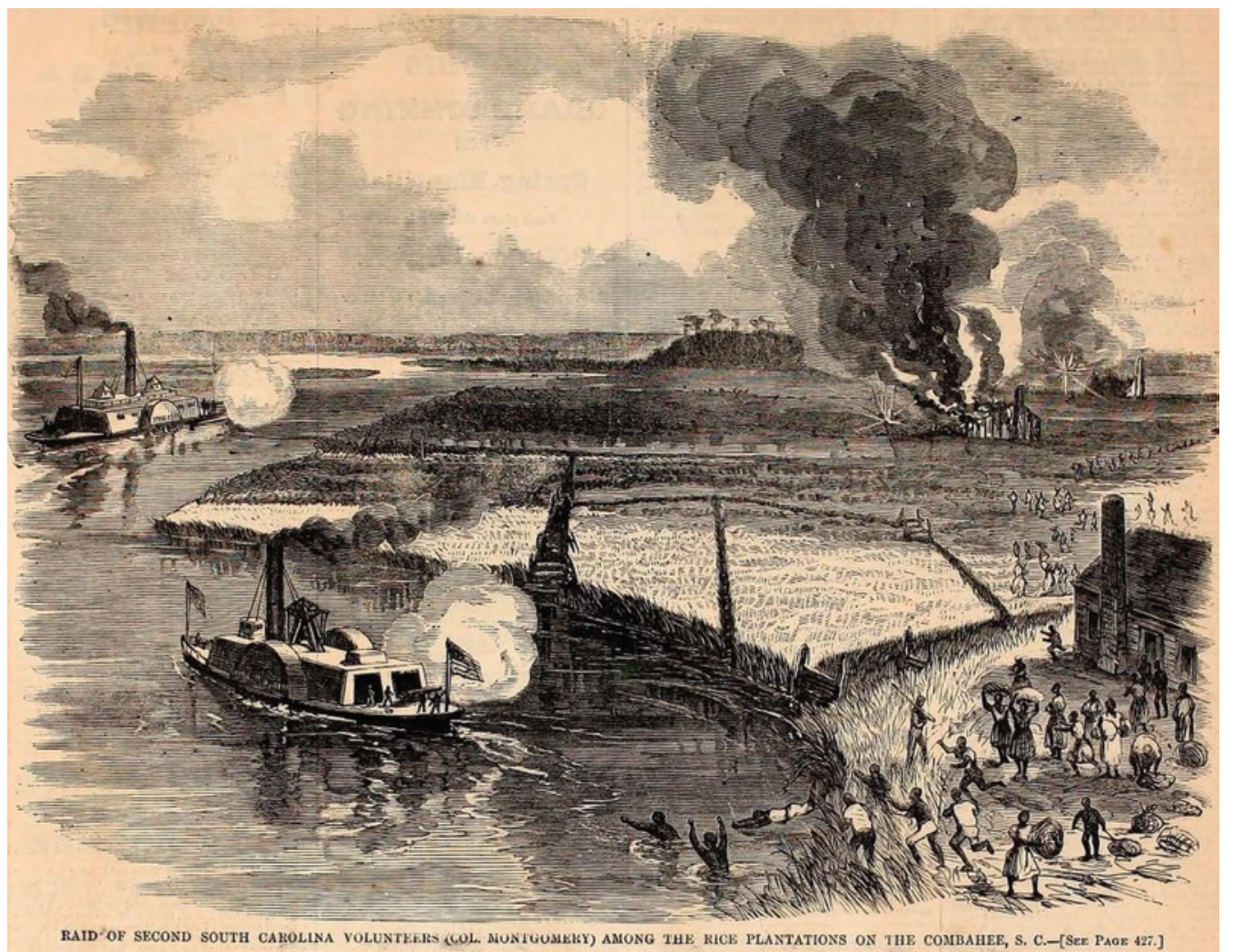

FIG. 11. Artist's rendering of the Combahee River Raid, from Harper's Weekly Magazine, July 4, 1863, p. 429. (Public domain: https://archive.org/stream/harpersweeklyv7bonn\#page/428/mode/2up)

\section{Conclusions}

The American Civil War era shook the nation down to its core, with head injury and its ramifications pervading the country. From the president of the US at that time, Abraham Lincoln, to soldiers on the battlefield, head injuries and their appropriate treatment were vital considerations. Fortunately, in comparison with prior wars, the tragedies and triumphs of the American Civil War were truly well documented, with a rich history that extends its reach into the culture of the United States of America even today. It has been estimated that in the war, approximately $10.7 \%$ of all wounds to the Union forces were head wounds, and that $94 \%$ of all wounds were caused by the firing of a minie ball. ${ }^{918,19}$ Both Major General John Sedgwick and First Lieutenant Alonzo Cushing perished from gunshot wounds to the head, as soldiers of the Union forces fighting to help end slavery and bring a divided nation together once again. Slavery was a major dividing point between the Union and Confederate ideologies. People such as Harriet Tubman, who sustained a significant head injury and a lifetime of seizures, played a major role as abolitionists during the Civil War era. All 3 of these individuals have greatly contributed to the free society that the US currently enjoys.

It seems very fitting that, more than 150 years later, the first African American president of the US bestowed the Congressional Medal of Honor on First Lieutenant Alonzo Cushing for his heroism at Gettysburg. Furthermore, it is interesting to note that Alonzo Cushing, being a direct descendant of Matthew Cushing, the first Cushing to come to
America, is in fact a distant relative of the father of modern neurosurgery, Harvey Cushing. 5,10,34

\section{References}

1. Adams SH: Grandfather Stories. New York: Random House, 1955

2. Allen TB, Bauer C: Harriet Tubman, Secret Agent: How Daring Slaves and Free Blacks Spied for the Union During the Civil War. Washington, DC: National Geographic Society, 2006

3. Baker P: Medal of Honor for a Civil War hero 150 years in the grave. New York Times. August 28, 2014; A1

4. Blaisdell FW: Medical advances during the Civil War. Arch Surg 123:1045-1050, 1988

5. Bliss M: Harvey Cushing: A Life in Surgery. New York: Oxford University Press, 2005

6. Blue R, Naden CJ: Harriet Tubman: Riding the Freedom Train. Brookfield, CT: Millbrook Press, 2003

7. Bradford SH: Harriet, the Moses of Her People. New York: JJ Little \& Co, 1901

8. Bradford SH: Scenes in the Life of Harriet Tubman. Auburn, NY: WJ Moses, printer, 1869

9. Brooks SM: Civil War Medicine. Springfield, IL: Charles C Thomas, 1966

10. Brown KM: Cushing of Gettysburg: The Story of a Union Artillery Commander. Lexington, KY: University Press of Kentucky, 1993

11. Chisolm JJ: A Manual of Military Surgery. Richmond, VA: West \& Johnston, 1861

12. Clinton C: Harriet Tubman: The Road to Freedom. New York: Little, Brown \& Co, 2004

13. Confederate States of America Surgeon-General's Office: A 
Manual of Military Surgery: Prepared for the Use of the Confederate States Army. Richmond, VA: Ayres \& Wade, 1863

14. Crewe SE: Harriet Tubman's last work: the Harriet Tubman Home for Aged and Indigent Negroes. J Gerontol Soc Work 49:229-244, 2007

15. Detmold W: Lectures on military surgery. Am Med Times 6-7, 1863

16. Formento F Jr: Notes and Observations on Army Surgery. New Orleans: LE Marchand, printer, 1863

17. Freidman WA, Peace D: A gunshot wound to the head-the case of Abraham Lincoln. Surg Neurol 53:511-515, 2000

18. Gabriel RA: Between Flesh and Steel: A History of Military Medicine from the Middle Ages to the War in Afghanistan. Washington, DC: Potomac Books, 2013

19. Gabriel RA, Metz KS: A History of Military Medicine. New York: Greenwood Press, 1992

20. Gillett MC: The Army Medical Department, 1775-1818. Washington, DC: Center of Military History, 1981

21. Gillett MC: The Army Medical Department, 1818-1865. Washington, DC: Center of Military History, 1987

22. Greenblatt SH, Dagi TF, Epstein MH: A History of Neurosurgery in Its Scientific and Professional Contexts. Park Ridge, IL: American Association of Neurological Surgeons, 1997

23. Grissinger JW: The development of military medicine. Bull N Y Acad Med 3:301-356, 1927

24. Gross SD: A Manual of Military Surgery. Philadelphia: JB Lippincott, 1861

25. Haight TW: Three Wisconsin Cushings. Madison, WI: Wisconsin History Commission, 1910

26. Hall TP: Family History of Lieut.-Colonel Frederick Füger. Detroit: Winn \& Hammond, 1904

27. Hamilton FH: Lectures on gunshot injuries of the head. Am Med Times 8-9, 1864

28. Hamilton FH: A Practical Treatise on Military Surgery. New York: Baillière Brothers, 1861

29. Hamilton FH: A Treatise on Military Surgery and Hygiene. New York: Baillière Brothers, 1865

30. Holt RB: A heroine in ebony. Chautauquan 23:459-462, 1896

31. Johnson RU, Buel CC: Battles and Leaders of the Civil War. New York: Century, 1887

32. Kaufman HH: Treatment of head injuries in the American Civil War. J Neurosurg 78:838-845, 1993

33. Larson KC: Bound for the Promised Land: Harriet Tubman, Portrait of an American Hero. New York: Ballantine, 2004

34. Lincoln S Jr: History of the Town of Hingham, Plymouth County, Massachusetts. Hingham, MA: C Gill Jr and Farmer \& Brown, 1827

35. Lowry B: Harriet Tubman: Imagining a Life. New York: Doubleday, 2007

36. McClellan GB, Prime WC: McClellan's Own Story: The War for the Union. New York: CL Webster, 1887

37. McGaugh S: Surgeon in Blue: Jonathan Letterman, the Civil War Doctor Who Pioneered Battlefield Care. New York: Arcade Publishing, 2013

38. McGowan JA, Kashatus WC: Harriet Tubman: A Biography. Santa Barbara, CA: ABC-CLIO, LLC, 2011

39. McPherson JM: Battle Cry of Freedom: The Civil War Era. New York: Oxford University Press, 1988

40. Montgomery JW: Resuscitation of President Lincoln. JAMA 176:160-162, 1961

41. Moran D: If You Will Lead: Enduring Wisdom for Twenty-First-Century Leaders. Chicago: Agate, 2011

42. Parker OW: The assassination and gunshot wound of President Abraham Lincoln. Minn Med 31:147-149, 1948
43. Petry A: Harriet Tubman, Conductor on the Underground Railroad. New York: Harper Trophy, 1996

44. Pfanz HW: Gettysburg-Culp's Hill and Cemetery Hill. Chapel Hill, NC: University of North Carolina Press, 1993

45. Ray FL: The killing of Uncle John. Civil War Times 45:2632, 2006

46. Rhea GC: The Battles for Spotsylvania Court House and the Road to Yellow Tavern, May 7-12, 1864. Baton Rouge, LA: Louisiana State University Press, 1997

47. Sedgwick J, Curtis GW: Correspondence of John Sedgwick, Major-General. New York: De Vinne Press, 1902

48. Sernett MC: Harriet Tubman: Myth, Memory, and History. Durham, NC: Duke University Press, 2007

49. Sifakis S: Who Was Who in the Civil War. New York: Facts on File, 1988

50. Simpson I: Obama awards officer Medal of Honor for Civil War heroism. Thomson Reuters. November 6, 2014. (http:// www.reuters.com/article/us-usa-medalofhonor-cushingidUSKBNOIQ24P20141106) [Accessed March 24, 2016]

51. Smith S: Hand-book of Surgical Operations. New York: Baillière Brothers, 1862

52. Sternbach GL, Varon J, Fromm RE Jr: Charles Augustus Leale and the resuscitation of Abraham Lincoln. Resuscitation 45:3-5, 2000

53. Taylor JS (ed): United States Naval Medical Bulletin, Vol 15, No. 1. Washington, DC: Bureau of Medicine and Surgery, Navy Department, 1921

54. Tripler CS, Blackman GC: Hand-book for the Military Surgeon. Cincinnati: Robert Clarke \& Co, 1861

55. Warren E: An Epitome of Practical Surgery for Field and Hospital. Richmond, VA: West \& Johnston, 1863

56. Welch ES: A Biographical Sketch: John Sedgwick, MajorGeneral. New York: De Vinne Press, 1899

57. White WG: Appropriate Treatment of Head Injuries by Surgeons During the Civil War [master's thesis]. Fort Leavenworth, KS: US Army Command and General Staff College, 2004

58. Winslow RE III: General John Sedgwick, the Story of a Union Corps Commander. Novato, CA: Presidio Press, 1982

59. Woodward JJ, Barnes JK (eds): The Medical and Surgical History of the War of the Rebellion. (1861-65). Washington, DC: Government Printing Office, 1870

60. Zellem RT: Wounded by bayonet, ball, and bacteria: medicine and neurosurgery in the American Civil War. Neurosurgery 17:850-860, 1985

\section{Disclosures}

The authors report no conflict of interest concerning the materials or methods used in this study or the findings specified in this paper.

\section{Author Contributions}

Conception and design: Prestigiacomo, Sabourin. Acquisition of data: Sabourin, Holland, Mau. Analysis and interpretation of data: Sabourin, Holland, Mau. Drafting the article: Sabourin, Holland, Mau. Critically revising the article: all authors. Reviewed submitted version of manuscript: all authors. Administrative/technical/ material support: Prestigiacomo, Gandhi. Study supervision: Prestigiacomo, Gandhi.

\section{Correspondence}

Charles J. Prestigiacomo, Department of Neurological Surgery, Rutgers New Jersey Medical School, 90 Bergen St., Ste. 8100, PO Box 1709, Newark, NJ 07101-1709. email: c.prestigiacomo@ njms.rutgers.edu. 